\title{
Perawatan Ehrlichiosis pada kucing yang mengalami anemia dan indikasi gagal ginjal
}

\author{
K. Kurnia ${ }^{1, *}$, D. Anggoro ${ }^{1}$, S. Budhi ${ }^{1}$, D. Priyowidodo ${ }^{2}$ \\ ${ }^{1}$ Rumah Sakit Hewan Prof. Soeparwi Fakultas Kedokteran Hewan Universitas Gadjah Mada, Yogyakarta \\ ${ }^{2}$ Departemen Parasitologi Fakultas Kedokteran Hewan Universitas Gadjah Mada, Yogyakarta
}

\begin{abstract}
ABSTRAK: Kucing persia diperiksa sebanyak 2 ekor diperiksa tanggal 23 April 2019 dan 29 April 2019 dengan gejala lesu, mukosa pucat, tidak mau makan sejak 3-5 hari, dehidrasi dan mengalami penurunan berat badan dalam satu bulan terakhir. Kucing tersebut berasal dari pemilik berbeda yang memungkin pernah kontak dengan anjing. Pemeriksaan klinis menunjukkan kedua kucing mengalami anemia, lethargi dan abnormalitas ukuran ginjal yang membengkak pada kucing I dan atropi pada kucing II. Hasil pemeriksaan laboratorium kedua kucing mengalami anemia, SGPT/ALT turun, albumin normal, blood urea nitrogen (BUN) dan creatinin keduanya meningkat. Kucing I mengalami trombositopenia, leukositosis dengan neutrofilia dan protein plasma normal. Kucing II menunjukkan trombosit normal, neutrofilia dan total protein yang meningkat. Pemeriksaan preparat apus darah ditemukan inklusi intrasitoplasmik dalam neutrofil dari kedua kucing yang mengarah pada morula Ehrlichia sp. Diagnosa kedua kucing mengarah pada dugaan Ehrlichiosis. Penanganan anemia dan dehidrasi diberikan infus $\mathrm{NaCl} 0,9 \%$ intravena, injeksi Meylon dan Hematodin. Kondisi kedua kucing terus menurun, kucing I mati setelah 2 hari terapi dan kucing II mati setelah 5 hari terapi.
\end{abstract}

Kata kunci:

Anemia, apus darah, Ehrlichiosis, kucing

\section{- PENDAHULUAN}

Ehrlichiosis pada kucing dilaporkan pertama kali pada tahun 1989 oleh Bouro dan rekannya saat mendiskripsikan adanya inklusi intrasitoplasmik monosit dan limfosit dari tiga ekor kucing di Kenya (Guimarães at al. 2019). Ehrlichiosis lebih dikenal sebagai parasit darah pada anjing dimana caplak Rhipicephalus berperan sebagai vektornya. Kejadian Ehrlichiosis sangat jarang ditemukan pada kucing, bersifat multisistemik dengan gejala klinis yang bervariasi tergantung pada stadium penyakit dan imunitas hospes. Hal ini seringkali membuat Ehrlichia tidak dipertimbangkan sebagai diagnosa penyakit pada kucing. Beberapa temuan klinis dan laboratorium dapat menjadi petunjuk kemungkinan adanya Ehrlichia (Barger \& Macneill 2015), meskipun dibutuhkan pemeriksaan PCR sebagai golden standard dalam diagnosa Ehrlichiosis. Tulisan ini melaporkan kasus pada 2 ekor kucing yang tidak tertolong di Rumah Sakit Hewan Prof. Soeparwi, Fakultas Kedokteran Hewan, Universitas Gadjah Mada, Yogyakarta.

\section{- KASUS}

Anamnesis, sinyalemen dan status pasien: Kucing I ras persia, jantan, usia 14 tahun, diperiksa tangal 23 April 2019 dengan keluhan penurunan nafsu makan yang progresif sejak 2 minggu sebelumnya, terlihat lesu, pucat, dan semakin kurus. Kucing dipelihara di dalam petshop yang menyediakan jasa penitipan dan grooming anjing dan kucing, pernah terjadi wabah caplak di petshop sekitar 2 bulan sebelumnya. Kucing II ras persia jantan, usia 1 tahun diperiksa tanggal 29 April 2019 dengan keluhan tidak mau makan sejak 3 hari sebelumnya, lesu, ambruk, adanya penurunan berat badan sejak 2 minggu terakhir. Kucing telah dipelihara selama 3 minggu dan berasal dari shelter anjing dan kucing. Kedua kasus menunjukkan kondisi pasien lesu, lethargi. Pemeriksaan klinis: BCS 2-3 (skala 9), dehidrasi, mukosa anemik, pembengkakan ginjal pada kucing I dan atropi ginjal pada kucing II, serta tidak ditemukan adanya obstruksi saluran urinaria pada kedua kasus. Pemeriksaan penunjang: pemeriksaan hematologi lengkap dan kimia darah (Harvey 2012). Diagnosa dan diagnosa banding: mengarah pada penyakit multisistemik yang mungkin disebabkan oleh Rickettsia dengan diagnosa banding Feline Infectious Peritonitis (FIP), hepatik lipidosis, hepatik amiloidosis, sirosis.

\section{- HASIL DAN PEMBAHASAN}

Temuan laboratorik hematologi dan apus darah dari kedua kasus menunjukkan adanya anemia yang terindikasi sebagai non-regeneratif dan akut-kronik inflamasi. Azotemia tanpa indikasi adanya obstruksi saluran urinaria mengarah pada prerenal/renal azotemia. Warna kuning pekat (ikterik) pada

Diterima: 03-02-2020 | Direvisi: 10-03-2020 | Disetujui: 15-03-2020

(C) 2020 CC-BY-SA. Ini adalah artikel Open Access yang didistribusikan berdasarkan ketentuan dari Creative Commons Attribution ShareAlike 4.0 International License (https://creativecommons.org/licenses/by-sa/4.0/). 
plasma maupun serum merupakan petunjuk penting terhadap indikasi hiperbilirubinemia. Ikterik tanpa adanya indikasi hemolitik anemia mengarah pada penyakit intrahepatik ataupun post-hepatik (Tabel 1).

Tabel 1. Hasil pemeriksaan hematologi dan kimia darah.

\begin{tabular}{|c|c|c|c|}
\hline Jenis Pemeriksaan & Kucing 1 & Kucing 2 & $\begin{array}{c}\text { Range } \\
\text { Normal }\end{array}$ \\
\hline Warna plasma/serum & $\begin{array}{l}\text { Kuning } \\
\text { pekat/ } \\
\text { ikterik }\end{array}$ & $\begin{array}{l}\text { Kuning pekat/ } \\
\text { ikterik }\end{array}$ & $\begin{array}{l}\text { Bening, sedi- } \\
\text { kit } \\
\text { kekuningan }\end{array}$ \\
\hline \multicolumn{4}{|c|}{ HEMATOLOGI } \\
\hline Hemoglobin (gr/dL) & 4.4 & 8.0 & $11.9-18.9$ \\
\hline Eritrosit $\left(\times 10^{6} / \mu \mathrm{L}\right)$ & 2.49 & 4.74 & $5.0-10.0$ \\
\hline Hematokrit (\%) & 14.0 & 24.0 & $30.0-45.0$ \\
\hline $\operatorname{MCV}(\mathrm{fL})$ & 56.2 & 50.6 & $39.0-55.0$ \\
\hline MCH (fL) & 17.7 & 16.9 & $13.0-17.0$ \\
\hline $\mathrm{MCHC}(\%)$ & 31.4 & 33.3 & $30.0-36.0$ \\
\hline RDW $(\%)$ & 13.9 & 16.3 & $13.0-18.0$ \\
\hline Leukosit $\left(\times 10^{3} / \mu \mathrm{L}\right)$ & 31.7 & 14.7 & $5.5-19.5$ \\
\hline \multirow{2}{*}{ Neutrofil $(\%)$} & 89.1 & 90.1 & $45.0-64.0$ \\
\hline & 28.2 & 13.2 & $2.5-12.5$ \\
\hline \multirow[t]{2}{*}{ Basofil } & 0.0 & 0.0 & $0.0-1.0$ \\
\hline & 0.0 & 0.0 & $0.0-0.2$ \\
\hline \multirow{2}{*}{$\begin{aligned} \text { Eosinofil } & (\%) \\
& \left(\times 10^{3} / \mu \mathrm{L}\right)\end{aligned}$} & 3.5 & 1.4 & $0.0-4.0$ \\
\hline & 1.1 & 0.2 & $0.0-0.8$ \\
\hline \multirow{2}{*}{$\begin{array}{ll}\text { Limfosit } & (\%) \\
& \left(\times 10^{3} / \mu \mathrm{L}\right)\end{array}$} & 4.9 & 6.3 & $27.0-36.0$ \\
\hline & 1.6 & 0.9 & $1.5-7.5$ \\
\hline \multirow{2}{*}{$\begin{array}{ll}\text { Monosit } & (\%) \\
& \left(\times 10^{3} / \mu \mathrm{L}\right)\end{array}$} & 2.5 & 2.2 & $0.0-5.0$ \\
\hline & 0.8 & 0.3 & $0.0-0.9$ \\
\hline Trombosit $\left(\times 10^{3} / \mu \mathrm{L}\right)$ & 78 & 544 & $300-800$ \\
\hline $\mathrm{TPP}(\mathrm{gr} / \mathrm{dL})$ & 6.5 & - & $6.0-7.5$ \\
\hline \multicolumn{4}{|c|}{ KIMIA DARAH } \\
\hline SGPT/ALT (IU/L) & 23.9 & 19.5 & $28.0-76.0$ \\
\hline SGOT (IU/L) & - & 22.0 & $5.0-55.0$ \\
\hline Albumin (gr/dL) & 2.94 & 3.95 & $2.4-4.1$ \\
\hline Globulin (gr/dL) & - & 6.25 & $2.6-5.1$ \\
\hline Protein serum (gr/dL) & - & 10.4 & $5.4-7.8$ \\
\hline $\begin{array}{l}\text { Bilirubin Total } \\
(\mathrm{mg} / \mathrm{dL})\end{array}$ & - & 2.02 & $0.0-0.4$ \\
\hline $\begin{array}{l}\text { Bilirubin direk } \\
(\mathrm{mg} / \mathrm{dL})\end{array}$ & - & 1.36 & $0.0-0.1$ \\
\hline $\begin{array}{l}\text { Bilirubin indirek } \\
(\mathrm{mg} / \mathrm{dL})\end{array}$ & - & 0.66 & $0.0-0.3$ \\
\hline BUN (mg/dL) & 200.81 & 200.05 & $15.0-34.0$ \\
\hline Creatinin (mg/dL) & 8.6 & 7.1 & $0.8-2.3$ \\
\hline
\end{tabular}

Pemeriksaan preparat apus darah menunjukan adanya rouleux, mild anisositosis dengan minimal polikromasia, dan adanya neutrofil band. Pemeriksaan apus darah lebih detail dilakukan ulang terlihat adanya inklusi intrasitoplasmik yang mengarah pada morula Ehrlichia sp. dalam jumlah sedikit selama fase infeksi akut (Gambar 1.). Deteksi morula Ehrlichia sp. intraseluler berbentuk khas, sangat spesifik untuk peneguhan diagnosa Ehrlichiosis (Straube 2010).

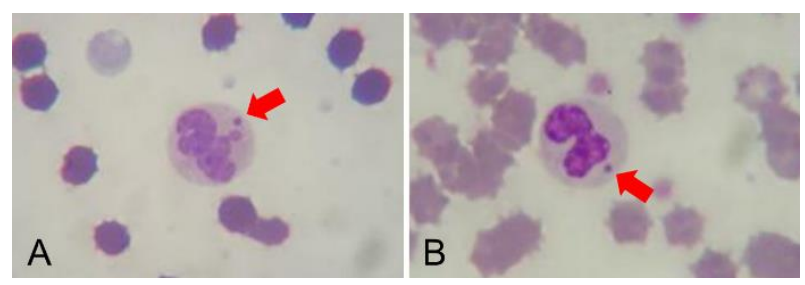

Gambar 1. Inklusi intrasitoplasmik neutroflil (panah merah) yang mengarah pada morula Erhlichia sp pada preparat apus darah Kucing 1 (A) dan Kucing 2 (B), pewarnaan Giemsa.
Ehrlichiosis menimbulkan gejala klinis dan perubahan patologis yang bervariasi sehingga menjadi tantangan dalam mendiagnosa (Villiers \& Ristic 2016). Tergantung pada stadium dan kondisi imunitas pasien (Thompson 2018). Anemia non-regeneratif, gagal ginjal dengan prerenal/renal azotemia, gangguan intrahepatik/post-hepatik pada kedua kasus menjadi petunjuk terhadap kemungkinan diagnosa Ehrlichiosis (Willard \& Tvedten 2012, Tilley et al. 2015). Keberadaan caplak yang memiliki beberapa hospes definitif selain anjing, dipertimbangkan dalam penularan Ehrlichiosis. Polymerase Chain Reaction (PCR) dibutuhkan untuk peneguhan diagnosa Ehrlichiosis.

Terapi untuk kedua kasus meliputi penanganan anemia dan dehidrasi berupa infus $\mathrm{NaCl} 0,9 \%$ intravena, injeksi Meylon (PT. Otsuka Indonesia) dan Hematodin (Romindo Primavetcom). Doxycyclin dapat dipertimbangkan untuk mengatasi Ehrlichiosis. Kondisi kedua pasien menurun, mati 2 hari terapi pada kucing I dan 5 hari terapi pada kucing II.

\section{- SIMPULAN}

Diagnosa ehrlichiosis sering tidak dipertimbangkan sebagai penyakit pada kucing. Temuan klinis dan pemeriksaan laboratorium dapat menunjang diagnosa.

\section{- INFORMASI PENULIS}

Penulis untuk Korespondensi

*KK: kurnia.dvm@gmail.com

RSH Prof. Soeparwi FKH-UGM, Jl. Fauna 1, Karangmalang, Catur-tunggal, Depok, Sleman, Yogyakarta.

\section{- UCAPAN TERIMA KASIH}

Terima kasih pada drh Dean Andre dari Jogja Pet Care Center, drh B. Brahmanto Aji, MSc dari Djio Pet Care, drh Sugiyono, MSc dan drh Sitarina Widyarini, PhD dari Departemen Patologi FKH UGM atas diskusi yang terkait Ehrlichiosis

\section{- PUSTAKA ACUAN}

Barger AM, Macneill AL. 2015. Clinical Pathology and Laboratory Techniques for Veterinary Technicians. Oxford: Wiley Blackwell

Guimarães A, Raimundo JM, Rodrigues RB, Peixoto MP, Santos HA, André MR, Machado RZ, Baldani CD. 2019. Ehrlichia spp. infection in domestic cats from Rio de Janeiro State, southeast Brazil. Revista Brasileira de Parasitologia Veterinária. 28(1):180-185.

Harvey JW. 2012. Veterinary Hematology: A Diagnostic Guide and Color Atlas. Missouri: Elsevier

Straube J. 2010. Canine Ehrlichiosis-from Acute Infection to Chronic Disease. Institute for Animal Hygiene and Veterinary Public Health, University of Leipzig, Germany. Disponible en línea en: http://www. cvbd. org/en/home/cvbd-digestarticles/(Acceso: 25.02. 2016).

Thompson MS. 2018. Small Animal Medical Diagnosis: A Book of List 3rd Edition. Missouri: Elsevier

Tilley LP, Smith Jr FW, editors. 2015. Blackwell's five-minute Veterinary consult: canine and feline. John Wiley \& Sons.

Villiers E, Ristic J. 2016. BSAVA Manual of Canine and Feline Clinical Pathology 3rd Edition. Gloucester: BSAVA

Willard MD, Tvedten H. 2012. Small Animal Clinical Diagnosis by Laboratory Methods. Missouri: Elsevier. 